\title{
A Paradigm Shift in Japan's Political Economy: From the Developmentalism to the Tourism based Country
}

\author{
Fumitaka Furuoka, Beatrice Lim Fui Yee, Roslinah Mahmud and Iwao Kato*
}

Japan is one of the first Asian country that consciously adopted the ideology of developmentalism in order to survive harsh competition among imperialist states in the $19^{\text {th }}$ century. This process was interrupted by World War II. After the war, Japan reinstated developmentalism in order to restore its war-torn economy. Before the 1980 s, Japan had reached the status of a fully industrialised nation. In terms of economic power Japan became on a par with Western industrialised nations. This success story was dubbed the "Japanese Miracle" (Johnson, 1982).

The pursuit of economic development in Japan was often conducted at the expense of other policy agendas, such as the protection of nature and environmental conservation. As a result, the country's rapid economic expansion during the 1950s and 1960s was accompanied by an equally rapid deterioration of environmental conditions. Broadbent described the quandary of development versus environment as a "growth-environment dilemma" (Broadbent, 1998). That is, Japan's conscious choice to adopt developmentalism had inevitably led to grave environmental consequences. Nevertheless, in the 1970s, the importance of protection of nature and the need for environmental conservation were increasingly recognised not only by Japan's ruling elite, who had relentlessly pursued developmentalism, but also by the general public (Mori, 2003). During that time, environment-related issues emerged as an important social and policy agenda. This has been widely recognized as a paradigm shift in Japan's development practices and it seemed as if Japanese society was quickly learning from its mistakes.

This study uses the concept of the 'social learning' process and looks at what had taken place in Japan during the crucial decades after World War II as well as earlier episodes prior to the war. It also examines the negative outcomes that the policy of developmentalism produced during the "Japanese Miracle" period of economic growth. More importantly, this paper analyses Japan's socio-economic transformation from the old paradigm (developmentalism) to new paradigm (tourism-based country).

This paper consists of six sections. Following the introduction, section two discusses developmentalism and examines its main features. Section three analyses Japan's policymaking system and explores the reasons behind the serious environmental degradation that occurred in the country. Section four introduces the concept of social learning and seeks to identify the learning process in the course of development and environmental conservation in Japan. Section five examines Japan's new political economy paradigm, the 'Tourism-based country.' The final section is the conclusion.

\section{Developmentalism and the 'Japanese Miracle'}

Developmentalism can be considered as a 'development-first policy' conducted at the expense of other national interests. It has been frequently observed that new states

\footnotetext{
* Fumitaka Furuoka, Beatrice Lim Fui Yee and Roslinah Mahmud are senior researchers at the School of Business and Economics Universiti Malaysia Sabah, Malaysia. Iwao Kato is Professor of Economics at the Faculty of Economics and Business Wako University, Japan.
} 
adopt developmentalism as a fundamental ideology during the period of stateformation and nation-building. In such cases, the government assigns top priority to economic development and tends to disregard other important agendas, including protection of nature and environmental conservation. It implements various development projects under the name of national interests, thereby linking economic development to national security. For example, Shibusawa et al. (1992) recognise two main characteristics of 'developmentalism': 1) pragmatism, and 2) an emphasis on economic goals. The researchers maintain that developmentalism is not rooted in any ideological tradition of liberalism and an emphasis is put on economic goals which are designed to serve the purpose of the state. Among other characteristics of developmentalism are strong nationalistic sentiments demonstrated by relatively new states in response to a Western-dominated world, and a tightly-knit web of collaboration among bureaucrats, big businesses and politicians, which leads the economic development of those states.

The Japanese government adopted developmentalism in order to compete with Western colonial powers after Japan re-opened its commercial and diplomatic relations with the outside world in 1868. Similarly, after World War II the Japanese government used all available resources to achieve high economic growth and resurrect the country's war-torn economy. As a consequence of a single-minded pursuit of developmentalism, Japan became the first example of an "economic miracle" in East Asia and the first Asian member of the "rich countries clubs", such as the Organisation for Economic Cooperation and Development (OECD) and the Group of Eight (G8) (Johnson, 1982). Behind Japan's success story lies the strong role of the government, which has been one of the critical elements in Japan's developmental mechanism. In order to achieve high economic growth, the Japanese government implemented various industrial policies to guide the country's economic and business activities.

By contrast, governments in other industrialised countries, notably the United States, tend to refrain from interfering with their national economies. These differences are detailed in Johnson's (1982) discussion on "developmental states" versus "regulatory states." Johnson dubs Japan's political and economic mechanism as the "developmental state", and contrasts it with the "regulatory state," whose economic roles are limited to maintaining competition, consumer protection, and so on, as is exemplified by the US. Johnson attributes the differences between the two types of states to the timing of the industrialisation process: those states that had been industrialised relatively early, i.e., by the end of the nineteenth century became regulatory states, while those late comers turned themselves into developmental states, leading the industrialisation drive in order to catch up with the forerunners (Johnson, 1982:19). According to this scheme, while the Japanese government has been playing the role of a "coach" in the country's economy, other governments preferred to remain "judges". The leading role of the government of a developmental state could be viewed as a "necessity" that would enable non-Western countries, including Japan, to join the global economy. Japan was the first Asian country that transformed itself into a developmental state. Johnson argues that successful developmental states have been quasi-revolutionary regimes, in which whatever legitimacy their rulers possessed came from an overarching social design, that is, economic development, which their societies accepted and they implemented (Johnson, 1999:52).

To achieve its ultimate goal, the Japanese government protected and promoted the interests of the big Japanese corporations and utilised the power of bureaucrats to guide development projects. As Pempel and Muramatsu (1995:34) observe, economic 
development has been persistently pursued as a national goal by Japan's business and political leaders since the Meiji Restoration in 1868 and with renewed enthusiasm after the World War Second. Achieving high levels of national economic growth has been the touchstone against which the long-time viability of politicians and the competence of national bureaucrats are measured.

\section{Old Paradigm of Japan's Political Economy in Japan: The 'Iron Triangle'}

With a strong developmental orientation in its political system, Japan has developed a "tripod system" of decision-making processes for setting national policies. The three main actors of Japan's policymaking are: (1) powerful politicians from the Liberal Democratic Party (LDP), (2) national bureaucrats, especially those with the Ministry of Finance and the Ministry of International Trade and Industry and (3) big Japanese corporations. This system - a so-called "Iron Triangle" - has dominated Japanese state capitalism for the last half century (Tabb, 1999:77). The system excludes other actors, such as civil society, small and medium industries (SMIs) and ordinary people, from participating in the policymaking process. Among the three actors comprising the triangle, the national bureaucrats occupy the dominant position. Although the Diet is stipulated to be the highest organ of state power and the sole law-making organ of the state, the national bureaucrats are perceived as having more influence in the Japanese policy-making system than politicians. As Terada notes, although the Japanese Constitution accords the highest powers to politicians, Diet's deliberations have been ritualised (Terada, 2000). Bureaucrats rule the government and play the major role in Japan's policymaking. Under the parliamentary cabinet system, the Cabinet has the right to control administration on behalf of the people and is the major policy-making apparatus. However, bureaucrats actually control even the Cabinet. They exert crucial influence on the policy-making process and can steer it to their own benefit (Hosono et al., 1997:21). The Ministry of International Trade and Industry (MITI) played an especially pivotal role in Japan's policymaking process. Johnson described the MITI as the strategist and planner of Japan's economic development and suggested that the real equivalent of the MITI in the US is not the Department of Commerce but the Department of Defence, which, by its very nature and functions, shares MITI's strategy. Thus, MITI-led Japan's industrial policy is similar to that surrounding the expression "military-industrial complex," which is a close working relationship between the government and business to solve the problem of national defence (Johnson, 1982:22).

\section{Paradigm Shift in Japan's Political Economy}

Japanese policymakers tend not to pay due attention to the opinions of the general public who have very little leverage on decision-making processes in the Japanese political economy. Time and again, the government has overlooked or underestimated serious side effects that development projects have caused to local communities. In such cases, the government expected local residents to sacrifice their rights for the sake of development while supporting the interests of private businesses. As a result, environmental and social issues began cropping up. The Japanese ruling elites began taking environmental considerations more seriously only in the 1970s. After some major cases of pollution had occurred in Japan, environmental conservation became an important national agenda. In other words, the change in discourse in the country's 
development and environmental conservation occurred only after Japan had encountered a number of serious pollution problems. In other word, Japan's "crude" developmentalism began transforming itself into the "tourism-based country" only after went through painful experiences of serious industrial pollutions. In other word, the developmentalism led to serious environmental population problems and subsequently to a paradigm shift in which the 'social learning' process played an important role.

The "social learning" process can be defined as a process by which society enhances its capacity to solve problems it faces through interaction among social actors. In many cases, those actors represent different and even contradictory interests. They are expected to learn about different positions on certain issues through dialogue, cooperation, communication and even dispute, and thus contribute to bringing about an optimal solution to problems (Newman, 2001:88-84, Fiorino, 2001:328-330). Two factors are important for social learning to take place.

First, actors should be well-established. Weak actors cannot function as advocates for certain positions, interests or values, which can be considered as resources that the society concerned possesses.

Second, the interaction among the actors should be constructive. Actions taken to undermine them such as repressive measures by government agencies are detrimental to social learning. What is said about society in social learning can be applied to the government as well. From the standpoint of policy-making, this is a process in which the results of social interaction are fed into the government's decision-making (Fiorino, 2001:322).

It is interesting to examine how social learning has taken place and helped to effect changes in Japan's environmental policies through discursive practices. A prominent Japanese environmental activist, Jun Ui identifies collective action as the most critical determining factor in Japan's environmental reform (Ui, 1989). In a similar vein, Broadbent asserts that the environmental movement was indispensable in bringing about Japan's environmental reform (Broadbent, 1998). The first of Japan's major pollution accidents known as "The Big Four" pollution cases, the Ashio copper mine pollution case, took place in the beginning of the 20th century. Demonstrations by local residents against the polluter did not produce much result initially, but Ashio copper mine protests did eventually influence the Japanese government's environmental policies later. As Ui argues, the course of events in the Ashio mine pollution case created awareness among polluting companies in subsequent cases, such as the Besshi and Hitachi mines cases, regarding the demands of the victims of pollution (Ui, 1992). Upham distinguishes three stages in the environmental movement in Japan: 1) petitions, 2) protests, and 3) litigation (Upham, 1987). This classification could be modified to include other phases of the environmental movement that had led to a policy change in Japan's environmental policies or the "social learning" process: (1) occurrence of a pollution incident, (2) denial of accusations by the culprit company and/or the government authority, (3) shift from a non-confrontational approach to confrontational actions, (4) legal actions and (5) policy change in the environmental policy (Furuoka and Lo, 2005). Each of these five stages of the social learning process will be discussed in detail in the following sub-sections.

\section{Stage One: Occurrence of Pollution Incident}

Since Japan's ruling elites, constituting the Iron Triangle, set the country on the development drive, "mega projects" had been undertaken to create the infrastructure required for its own economic development. In the pursuit of development, negative impacts that development projects had made on the environment were not sufficiently 
recognised, and public opinion and concerns, not seriously taken into account. As a result, industrialisation was accompanied by serious pollution. For several decades during Japan's industrialisation drive, the environmental concerns had been a matter of a secondary importance. The primary issue was exploiting and mobilising all possible resources to speed up economic development. The prevailing belief in the "developmental state" had been that the benefits of economic development would outweigh the cost of pollution. As first became evident in the Ashio copper mine pollution case, the perception that economic benefits accrued for the country were far more important than the well-being of the people was very strong among the decisionmakers in Japan (Martinez-Alier, 2003). In this stage, the ruling elites were promoting "public interests" as they interpreted the term. The ideological milieu was such that people who took actions against a company serving "public interests" were labelled as subversive to Japan's national interests and, in some cases, to national security as well. As Ui observes, farmers who demonstrated against Furukawa Corporation, the owner of the copper refinery factory, were subjected to national security restrictions (Ui, 1992). These farmers were regarded by the authorities as "trouble makers" who threatened national security, and stern measures were taken against them.

It should be noted that in this stage, the general public was not ready to support the cause of the victims of pollution who had been projected as a threat to national security. Fujikura notes that in the early stages of social learning process in Japan, participants in anti-pollution activities were regarded unfavourably by general public (Fujikura, 2001:471).

\section{Stage Two: Denial of Accusations}

Whenever a pollution incident occurred, the culprit company would usually deny either the existence of pollution or the causal relationship between the pollution and deterioration in the health of local residents. There have been cases when the polluters used their political connections to intimidate local residents and prevent or stop investigations into pollution incidents. For example, in the Minamata pollution case, the culprit company used its political influence to prevent investigations into the source of an "unknown disease" that had afflicted local residents (Ui, 2001). A similar pollution case occurred in the Jinzu River basin (Toyama Prefecture) in 1955. A general practitioner with a private clinic in the polluted area alerted the general public to the nature of Itai-itai disease (Yoshida et al., 1999:217). However, the polluting company, Mitsui Mining and Smelting Corporation, denied its moral and legal responsibility. A study group formed by the Japanese Government to inquire into the source of the disease concluded that nutritional deficiencies were one of the causes for the outbreak of the disease. In this type of conflict between the suffering people and the companies responsible for the pollution, the Japanese Government usually protected the interests of the latter. As Martinez-Alier notes on the Ashio copper mine pollution case, Furukawa Corporation, the culprit company, had been benefiting from the novel and uncertain circumstances surrounding the chemical pollution, and from the close relationship between the government and business in Japan (Martinez-Alier, 2000).

\section{Stage Three: Shift from Non-Confrontational Approach to Confrontational Actions}

Local residents affected by pollution attempted to improve their situations by bringing petitions to the polluting companies or the government. However, this failed to achieve the desired results as the culprit companies and the government authorities refused to recognise the occurrence of pollution or admit their responsibilities and/or obligations toward local residents. This left the victims of pollution no other choice 
but to change their tactics and shift from a non-confrontational approach to confrontational actions. For example, in the early 1950s, the local residents petitioned a polluting company, Chisso Corporation, as symptoms of an "unknown disease" had been spreading in Minamata. The Chisso Corporation, however, denied being responsible for the pollution. The victims then resorted to a confrontational approach that included demonstrations and sit-ins. As Almeida and Stearns describe the course of events in Minamata, members of the "Mutual Assistance Society" including local fishermen began public rallies and disruptive protests in the late 1950s. In late November 1959, they escalated their struggle by holding a month-long sit-in outside the gate of a Chisso factory and demanded compensation. The subsequent media coverage helped to raise public awareness of the issue and highlighted the plight of the victims of pollution in Minamata (Almeida and Stearns, 1998:43). In Japan, a confrontational approach proved to be far more effective than a non-confrontational approach in bringing about environmental reform. This fact is noted by McKean who comments that the environmental movement in Japan has always started with ineffective antipollution petitions and gradually adopted more effective confrontational actions, including sit-ins, demonstrations, and electoral campaigning (McKean, 1981).

\section{Stage Four: Legal Actions}

Legal actions have been an important part of environmental social learning in Japan. As Vosse remarks, when the government and companies responsible for pollution incidents refuse to hold dialogue with the victims of pollution, people have only one way to proceed, i.e. go to court (Vosse, 1996). Thus, in 1972, the residents of the Toyama district who suffered from Itai-Itai disease resorted to legal action against the polluting company since the government-sponsored research team had found no causal relations between the pollution of the environment and the outbreak of the "unknown disease" (Yoshida et al., 1999:216).

Similarly, in the Minamata pollution case, local residents brought the issue to court even though Chisso Corporation had finally agreed to pay a small amount of compensation to the victims and their families in December 1959. The minor concessions Chisso Corporation offered did not satisfy the people, as these amounts were far less than what the Mutual Assistance Society had originally demanded (Almeida and Stearns, 1998). People sought fair compensation and, in 1973, the matter was brought to court (Lasdon, 1974:47). In those cases, the court usually protected the interests of the plaintiffs. Almeida and Stearns identify two major reasons for the court rulings favourable to the victims. First, strong support and sympathy for the victims of pollution had been formed by the general public due to nation-wide social movements against pollution. There was, therefore, public pressure for favourable verdicts. Second, court hearings progressed with such a speed that there was often little time for industrialists to manipulate the legal system. Thus, in the case of Minamata, for example, the court ruled in favour of the plaintiffs in March 1973 (Almeida and Stearns, 1998:50).

\section{Stage Five: Policy Change in Japan's Environmental Policy}

The four phases discussed above have resulted in the policy change in Japan's environmental policy. This is signified by the alteration of the local and central governments' attitudes towards environment, and the implementation of effective environmental control measures by the authorities as well as by culprit companies (McKean, 1981; Upham, 1987). Several points can be made about this change. 
First, the confrontational approach adopted by environmental campaigners has been quite effective in bringing about the change. Japan's social milieu was such that it was only through a confrontational stance that they were able to act effectively as carriers of certain social values in their interactions with companies and the government.

Second, to promote their cause, environmental campaigners took advantage of democratic institutions in Japan, such as the relatively independent media and judiciary and the electoral system.

Third, it seems that develomentalism had lost its erstwhile lustre by the 1970s. An increasing number of pollution cases were obviously one of the reasons for this. It can also be explained by the country's economic success, which might have rendered the national elites more flexible and accommodating.

Fourth, and somewhat related to the third point, environmental movements, even when adopting a confrontational approach, no longer posed a threat to national security as they once did. As those movements ceased to be perceived in security terms, there were fewer occasions on which the authorities took repressive measures against them.

\section{The New Paradigm in Japan's Political Economy: the 'Tourism-based Country'}

Japanese Prime Minister Junichiro Koizumi made a historical announcement in February 2002 to designate tourism as the key industry in the Japanese economy. According to the Ministry of Land, Infrastructure and Transport (MLIT), Koizumi made the policy speech in 2002, when the FIFA World Cup games were held in Japan. In his speech, Prime Minister Koizumi promised that the Japanese government would make serious efforts to increase the number of foreign tourists in Japan. Since then, MLIT agues, "the promotion of tourism has been a pillar of Japan's policy" (MLIT, 2007). Furthermore, Koizumi set up the Japan Tourism Advisory Council which would hammer out the basic strategy for tourism promotion in 2003. Prime Minister Koizumi himself presided over the first meeting of the council which was held at the Prime Minister's Official Residence in January 2003. In the meeting Koizumi announced that he would like to work toward the goal of revitalizing regional economies by bringing dormant tourism resources back to life and doubling the number of foreign tourists visiting Japan 2010 (Kantei, 2003). Koizumi also pointed out that the Japan Tourism Advisor Council would compile a report on the basic modalities for becoming a "tourism-based country" by taking a broad perspective (Kantei, 2003). To achieve the bold target to attract 10 million foreign tourists, the Japanese government launched the "Visit Japan Campaign" in 2003, with "Yokoso Japan! (Welcome to Japan!)" as a catchphrase. The campaign focused on the following countries and regions: South Korea, Taiwan, United States, China, Hong Kong, United Kingdom, Germany, France. Under the campaign, Prime Minister Koizumi himself appeared in promotional videos to invite foreign tourists to Japan (MLIT, 2007). Overseas visitors to Japan have gradually but steadily increased since the 2003 due to the various campaigns for tourism promotion. As Figure 1 shows, the number of foreign visitors to Japan was 4.7 million in 2001. The number of foreign visitors to Japan increased to 5.2 million in 2002, and the number remained the same in 2003. These two years are not good measures for the efficacy of Japan's campaigns for tourism promotion due to a worldwide decrease in tourism following the terrorist attacks of September 11, 2001 in the United States and the outbreak of SARS (primarily in Asia) in 2003. However, the Japanese government's efforts for tourism promotion seemed to bear fruits after 
2004. The number of foreign visitors to Japan drastically increased to 6.1 million in 2004 and to 6.7 million in 2005. In 2007, number of foreign tourist arrivals reached 7.1 million (Japan Travel Bureau, 2006).

Figure 1: Foreign Visitor Arrivals in Japan (in millions)

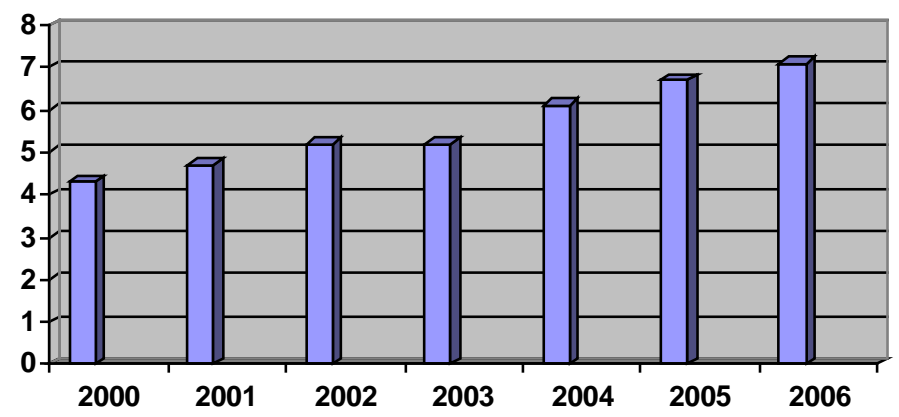

$\square$ Foreign Tourists

Source: JTB (2006)

Japan's national policy for making Japan a 'tourism-based country' could be considered as more environmentally friendly than the previous developmentalism policy. This is partly because this policy is closely linked with other national policies for making Japan a 'beautiful country.' In other words, a beautiful natural environment could be considered as Japan's most important tourism resource. The Japanese government recognised that tourism could play an important role in revitalising the Japanese economy and that the tourism industry could not thrive without strong environmental protection and conservation.

In short, in the old paradigm of Japan's political economy, the protection of nature and environmental conservation was considered of secondary importance. In the new paradigm, environmental conservation has become an important prerequisite for its key industry - tourism.

\section{Conclusion}

Japan was the first Asian country to adopt developmentalism as the dominant economic policy in the middle of the $19^{\text {th }}$ century. Development-driven policies helped Japan to reach an economic and political status on a par with developed Western nations within a few decades. In the decades following World War II, developmentalism helped to resurrect the war-torn Japanese economy and brought about the "Japanese miracle". However, impressive economic achievements in the 1950s and 1960s were overshadowed by serious environmental deterioration and destruction of the natural environment because Japan's policy makers' top priority was economic development at any cost. An overhaul of Japan's environmental policies began when the ruling elites finally began considering the issues of environmental conservation and pollution control after the nation went through very painful experiences resulting from serious pollution. The policy of crude developmentalism that Japan had espoused eventually began giving way to more environmentally-friendly development policies, such as "tourism-based country". To a considerable extent, this transformation was made possible due to the social learning process that had been evolving in Japan during that period. 
The 'social learning' process has also highlighted the importance of collective action in bringing about the discursive change in the country's environmental policy. The environmental conservation became issues of equal importance to the issue of economic development only after the collective actions against environmental pollution and polluting companies were successful in punishing polluting companies through civil lawsuits and raising public and governmental awareness about the detrimental effects of unchecked pollution on the environment had gained momentum.

Organised protests and confrontational actions by the victims of pollution and their supporters were a critical element in Japan's social learning process and helped to bring about the changes in the discourse practice. As Broadbent observes, the confrontational actions and protests by the people resulted in a better pollution control in Japan (Broadbent, 1998).

Japan's tumultuous experience in finding ways to reconcile the need for economic development with demands for the environmental conservation could provide valuable lessons for developing countries that have embarked on the path of developmentalism. It highlighted that environmental protection and tourism policies that emphasise a beautiful environment were vital to economic progress - that is, that the economic benefits of a tourism-based economy were equal to or better than those of a "developmentalist" economy. If not given proper consideration when policy makers draw up roadmaps for economic development, environmental issues will inevitably arise in developing countries pursuing developmentalist policies after considerable economic and social costs had been inflicted on such countries and their citizens.

\section{References}

Almeida, Paul and Linda B. Stearns (1998), "Political Opportunities and Local Grassroots Environmental Movement: The Case of Minamata", Social Problems, Vol.45, No.1.

Broadbent, Jeffrey (1998), Environmental Politics in Japan, Cambridge, Cambridge University Press.

Fiorino, D. J. (2001), "Environmental Policy As Learning: A new View of an Old Landscape", Public Administration Review, Vol. 61, No. 3.

Fujikura, Ryo (2001), "A Non-Confrontational Approach to Socially Responsible Air Pollution Control: Electoral Experience of Kitakyushu", Local Environment, Vol.6, No.4.

Furuoka, Fumitaka and Lo, May Chiun, (2005), "Japanese Multinational Corporations and the Export of Pollution: The Case of Bukit Merah", Electronic Journal of Contemporary Japanese Studies, posted on April 25.

Hosono, Sukehiro, Hideki Shiroyama and Hiroshi Suzuki (1997), "Chuo shocho-no seisaku keisei katei: nihon no kanryosei-no kaibo (Policy Formation Process in the Central Government: Anatomy of Japanese Bureaucracy)", Tokyo: Chuo University Press.

Japan Travel Bureau (JTB) (2006), “Travel Prospect 2006”, http://www.jtbcorp.jp, [accessed on March 11, 2007].

Johnson, Chalmers (1982), MITI and the Japanese Miracle: The Growth of Industrial Policy 1925-1975, Stanford: Stanford University Press. 
Johnson, Chalmers (1999), "The Developmental State: Odyssey of a Concept", in Meredith Woo-Cumings (ed.) (1999), The Developmental State, Inthaca: Cornell University Press.

Lasdon, Elizabeth S. (1974), "The Tragedy of Minamata", Business and Society Review, (Fall), No.15.

Martinez-Alier, Joan (2000), "Environmental Justice, Sustainability and Valuation", paper presented at the Harvard Seminar on Environmental Values, March 21.

McKean, M. (1981), Environmental Protests and Citizen Politics in Japan, Berkeley, CA, University of California Press.

Ministry of Land, Infrastructure and Transport (MLIT) (2007), "Overview of Japan's Tourism Policy,” http://www.mlit.go.jp/sogoseisaku/kanko/english/overview. html, [accessed on March 6, 2007]

Ministry of Land, Infrastructure and Transport (MLIT) (2005), "White Paper on Land, Infrastructure, and Transport in Japan, 2005", http://www.mlit.go.jp/, [accessed on March 6, 2007]

Mori, Michiya (2003), "Kodoseicho-ki no Kankyo-seiji (Environmental Politics in the Period of Rapid Economic Growth”, Seisaku Kenkyu (Policy Science), Vol. 11, No.1, pp.141-152.

Newman, H. K. (2001), "Historic Preservation Policy and Regime Politics in Atlanta", Journal of Urban Affairs, Vol. 23, No. 1.

Pempel, T.J. and Michio Muramatsu (1995), "The Japanese Bureaucracy and Economic Development: Structuring a Proactive Civil Service”, in Hyung-Ki Kim, Michio Muramatsu, T.J. Pempel and Kozo Yamamura (eds.) (1995), The Japanese Civil Service and Economic Development: Catalysts of Change, New York: Oxford University Press.

Prime Minister's Official Residence (Kantei) (2003), "The First Meeting of the Japan Tourism Advisory Council”,, http://www.kantei.go.jp/foreign/koizumiphote/ 2003/01/24kanko_e.etml. [accessed on March 7, 2006]

Shibusawa, Masahide, Z̄akaria Haji Ahmad and Brian Bridge (1992), Pacific Asia in the 1990s, London: Routledge.

Tabb, William K (1999), "The End of the Japanese Post-war System", Monthly Review, Vol. 51, No.3, (July/August).

Terada, Takashi (2000), "New Aspects of the Politicians-Bureaucrats Relations in Japan: Diet Reforms and Implications for the Policymaking System", paper presented at the International Conference on the Japanese Model, 29-30 March, 2000, Nikko Hotel, Kuala Lumpur, Malaysia.

Ui, June (1989), “Anti-Pollution Movements and Other Grass-Roots Organization", in S. Tsuru and H. Weidner (eds.), Environmental Policy in Japan, Berlin, Edition Sigma.

Ui Jun, ed. (1992), “Industrial Pollution in Japan”, Tokyo: Untied Nations University Press.

Ui, June (2001), "Interview with Jun Ui”, http://swave.atlas.co.jp/swave, [accessed July 11, 2001].

Upham, Frank K. (1987), Law and Social Change in Post-war Japan, Cambridge, MA, Harvard University Press.

Vosse, Wilhelm (1996), "The Past, Present and Future of the Environment Movement in Japan", the paper presented at the International Symposium on the Environmental Education and Environmental Ethics, Konan University, Kobe, on December 14, 1996. 
Yoshida, Fumikazu, Akio Hata and Haruo Tonegawa (1999), "Itai-Itai Disease and the Countermeasures Against Cadmium Pollution by the Kamioka Mine", Environmental Economics and Policy Research, Vol.2. 